\title{
A new approach to assessing occupational exposure to antineoplastic drugs in hospital environments
}

\author{
Stefano Dugheri ${ }^{1,2}$, Alessandro Bonari ${ }^{2}$, Ilenia Pompilio ${ }^{2}$, Pierpaolo Boccalon $^{1}$, Nicola Mucci ${ }^{2}$, and \\ Giulio Arcangeli1,2 \\ Careggi University Hospital, Medicina del Lavoro - Laboratorio di Igiene e Tossicologia Industriale ${ }^{1}$, University of \\ Florence, Dipartimento di Medicina Sperimentale e Clinica², Florence, Italy
}

[Received in March 2018; Similarity Check in March 2018; Accepted in June 2018]

Cytotoxic antineoplastic drugs (ADs) pose occupational risk and therefore require safe handling practices. We created, optimised, and validated an innovative monitoring protocol for simultaneously assessing 21 ADs in the healthcare environment, and also proposed surface exposure levels (SELs) to facilitate the interpretation of monitoring results, as there are currently no occupational exposure limits for ADs. The environmental AD monitoring data were collected in nine Italian hospitals between 2008 and 2017 and include 74,565 measurements in 4,814 wipe samples. Excellent overall recovery and sensitivity of the analytical methods along with innovative desorption automation make this protocol useful for routine monitoring. AD contamination was found in 3,081 measurements, confirming potential exposure in healthcare workers. Samples taken at the beginning and the end of work shifts, allowed to calculate $75^{\text {th }}$ and $90^{\text {th }}$ percentile values for each ADs both in preparation and administration units and we created a traffic-light colour-coding system to facilitate interpretation of the findings. The introduction of SELs will provide a solid basis for improving occupational safety and focusing on contamination control.

KEY WORDS: inductively coupled plasma mass spectrometry; liquid chromatography-mass spectrometry; surface contamination; wipe test; workplace safety

According to the World Cancer Research Fund International (1), the age-standardised rate for all cancers in men and women combined was 182 people per 100,000 in 2012, and in 2035, there will be around 24 million new cases of cancer around the world. Pacific Asia has been identified as a rather lucrative region for the anti-cancer drug market owing to the rising awareness of the availability of advanced therapies (2). In China, nearly four million new tumour cases appear every year, and by 2021, the total output of cytotoxic drugs is expected to reach 1,000 tonnes (3) with an estimated compound annual growth rate between $7.1 \%$ and $7.4 \%$ of the global market $(4,5)$. Furthermore, antineoplastic drugs (ADs) like cyclophosphamide (CP) and methotrexate (MT) have proved beneficial against nonmalignant diseases too, such as rheumatoid arthritis and multiple sclerosis, and their use is expected only to increase.

The National Institute for Occupational Safety and Health (NIOSH) (6) has recently released its updated list of hazardous drugs and has estimated that millions of healthcare workers - those who prepare and administer these medications to patients with cancer and other conditions - run the risk of exposure to these hazardous drugs at their workplace. The list includes chemotherapy drugs, many of which are mutagenic and carcinogenic (7).

Correspondence to: Stefano Dugheri, Azienda Ospedaliero-Universitaria Careggi, Largo P. Palagi, 1, 50139 Firenze, Italy

E-mail: stefano.dugheri@unifi.it
Concerns about occupational exposure to ADs were first expressed in the 1970s, and studies continue to evidence healthcare worker susceptibility. Ratner et al. (8) reported higher risk of breast cancer and reproductive health effects in nurses employed in oncology units. Hall et al. (9) show that about 75,000 Canadians $-0.42 \%$ of the total workforce - are occupationally exposed to ADs, $75 \%$ of whom are women. In Italy, of the 331 oncology wards surveyed, 256 have a centralised antineoplastic drug (AD) preparation unit, employing a total of 7,000 operators (10). As the usage and number of these drugs increase, so do opportunities for exposures (11).

The basic occupational health approach to minimising exposure risks combines several industrial hygiene control methods in a specific order or hierarchy. One of these methods, environmental monitoring, enables us to pinpoint contamination trends, identify corrective measures, and increase workers' awareness. In the case of cytotoxic ADs, monitoring surface contamination in hospital environments usually involves wipe tests as a simple way to indirectly assess dermal occupational exposure (12). However, most of the monitoring (13-20) is focused on no more than five ADs among the following drugs: CP, MT, iphosfamide (IP), paclitaxel (PTX), doxorubicin (DXR), 5-fluorouracyl (5FU), docetaxel (DTX), epirubicin (EPI), and gemcitabine (GEM). Only a few (21-23) have expanded the range from seven to ten [5-FU, PTX, CP, IP, MT, GEM, DXR, EPI, 
vincristine (VNC), vinblastine (VNB), docetaxel (DTX), etoposide (ETP), cytarabine (CTB), irinotecan (IRT), oxaliplatin, and vindesine].

Yet, no occupational exposure limits exist for ADs in any work environment. Sessink (24) proposed CP reference values for a traffic-light colour-coding model that would help interpret the findings in terms of exposure risk, where green is safe, amber alerting, and red means high risk. Kiffmeyer et al. (22), instead, produced a substanceindependent guideline based on the $90^{\text {th }}$ percentile values of eight ADs (CP, DTX, ETP, 5-FU, GEM, IP, MT, and PTX). Stricter Threshold Guidance Values (TGVs) for platinum $(\mathrm{Pt})$ and $5-\mathrm{FU}$, such as the $50^{\text {th }}$ or $75^{\text {th }}$ percentile, have been suggested by Schierl et al. (25) and Böhlandt and Schierl (26). In addition, Hedmer et al. (27) put forward Hygienic Guidance Values (HGVs) for CP and IP for different categories of surfaces at hospital workplaces. Most recently, Sottani et al. (28) have recommended HGVs for four ADs based on the $90^{\text {th }}$ percentile of wipe-sampling data distributions.

In the present work we propose our innovative surface monitoring protocol for multiple classes of ADs, while, at the same time, automating and standardising the procedure to considerably decrease the time needed for sample preparation and analysis. In addition, we propose surface exposure levels (SELs) for twenty-one ADs.

\section{MATERIALS AND METHODS}

\section{Experimental design}

To evaluate AD contamination of work surfaces, we evaluated 4,814 wipes (Table 1) from nine hospitals located in the northern, central, and southern Italy from 2008 to 2017. Sampling included 9 cytostatic preparation and 17 administration units. The volume of $\mathrm{AD}$ administrations ranged from 18,011 to 48,086 per hospital per year. Hospital programs followed the Italian guidelines (G.U. 236, 7.10.1999), specifically: i) staff were trained and re-trained in safety equipment and maintenance, research updates, and emergency care); ii) closed system devices were used for drug transfer between preparation and administration units to prevent any escape of hazardous drugs (ChemoClave,
ICU Medical Inc., San Clemente, USA; CareFusion, Becton Dickinson, Franklin Lakes, USA; Cyto-Set, B-Braun, Milan, Italy); and iii) specific cleaning products were utilised for floors ( $0.2 \%$ Marseille soap solution, $0.115 \%$ sodium hypochlorite, and $70 \%$ ethanol, in this order) and for small surfaces (Alcavis Bleach-Wipe 1:50, Angelini Pharma Inc., Gaithersburg, MD, USA) such as the laminar flow hoods, syringe pumps, and phone handsets. In one hospital, hazardous drugs were reconstituted and prepared with a Diana Hazardous Drug Compounding System (ICU Medical Inc., San Clemente, CA, USA), a needle-free, user-controlled automated compounding system. The centralised AD preparation units, protected by an anteroom, were all equipped with four IIA2-class biological safety cabinets.

The levels of CP, 5-FU, IP, MT, GEM, EPI, PTX, DTX, VNC, VNB, ETP, CTB, IRT, dacarbazine (DC), mitomycin C (MITC), doxorubicin (DXR), topotecan (TPT), melphalan (MP), idarubicine (IDC), fotemustine (FTM), and Pt - as a marker of cis -, carbo-, and oxaliplatin - were all measured in each wipe sample (altogether 74,565 measurements). Trophosphamide, daunorubicin, cephalomannine and 5-chlorouracil were chosen as internal standards for liquid chromatography (LC)-triple quadrupole mass spectrometry (MS/MS) quantification.

\section{Wipe sampling}

Wipe samples were collected from the preparation and administration units at the beginning (B-WS) and at the end of the work shift (E-WS). When possible, the samples were also collected in the middle of the shift. We used a standardised kit, which comprises all the necessary tools (Figure 1): $5 \times 5 \mathrm{~cm}, 3$-layer nonwoven fabric wipes (Cat. No. 26015Y, 6-layer Luxor-Net, STS Medical Group Luigi Salvadori, Scandicci, Italy) wetted with $500 \mu \mathrm{L}$ of an equimolar water/methanol solution, stored in a wipe cartridge kit (WCK) (Figure 2) developed by Chromline (Prato, Italy), assembled with $0.2 \mu \mathrm{m}$ GHP Acrodisc $13 \mathrm{~mm}$ filters (Cat. No. PN4567, Pall Corporation, New York, NY, USA) and connected to a $2 \mathrm{~mL}$ vial by a joint, tweezers with a joint for disposable pipette tips, as well as a precise instruction manual with photos and a video on the correct technique for obtaining wipe samples.

Table 1 Number of wipe samplings on each surface in the preparation and administration units

\begin{tabular}{lccccccc} 
& \multicolumn{3}{c}{ Preparation units } & \multicolumn{5}{c}{ Administration units } \\
\cline { 2 - 8 } & B-WS & E-WS & $\sum$ & B-WS & E-WS & $\sum$ & Total \\
\hline Floor & 142 & 138 & 280 & 468 & 384 & 852 & 1132 \\
\hline Door handle & 228 & 254 & 482 & 303 & 293 & 596 & 1078 \\
\hline Bed area & N/A & N/A & & 419 & 319 & 738 & 738 \\
\hline Laminar flow hood & 338 & 309 & 647 & N/A & N/A & 647 \\
\hline WC & N/A & N/A & & 80 & 351 & 700 & 1074 \\
\hline Other surfaces & 180 & 194 & 374 & 349 & 1412 & 3031 & 4814 \\
\hline Total & 888 & 895 & 1783 & 1619 & & 145 \\
\hline$B$-WS = before the work shift; $E-W S=$ end of the work shift; $\sum=$ sum of B-WS and E-WS values; N/A $=$ not-applicable
\end{tabular}




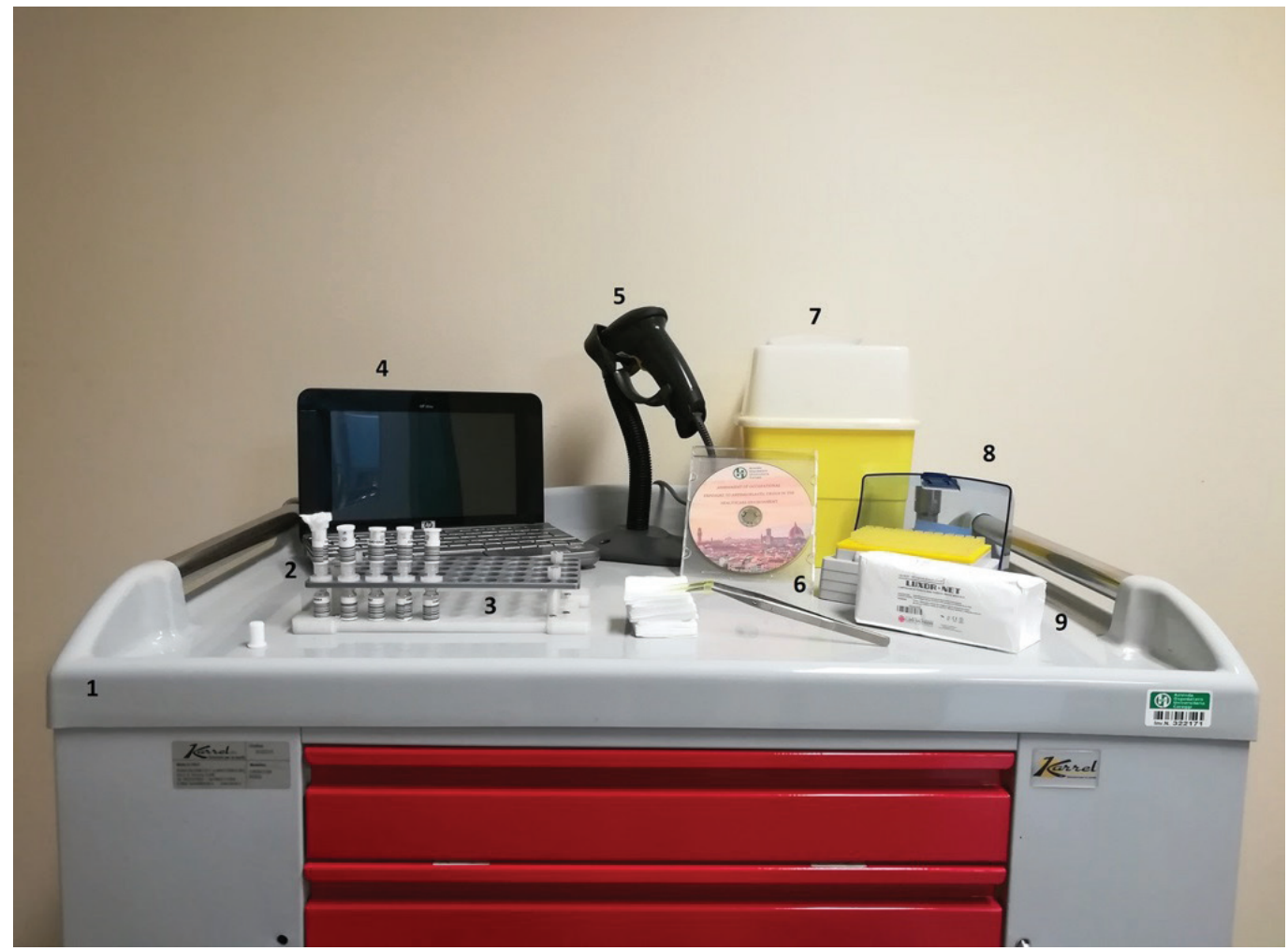

Figure 1 Wipe sampling kit: 1) wheel-trolley; 2) wipe cartridge kit (WCK) used for automatic desorption, preassembled with $5 \times 5 \mathrm{~cm}$, 3-layer nonwoven fabric; 3) 50-position WCK trays; 4) personal computer; 5) barcode reader; 6) CD instruction manual with photos and a video on the correct technique for obtaining wipe samples; 7) tweezer tip waste container) 8) tweezer tips; 9) $5 \times 5 \mathrm{~cm}$, 3-layer nonwoven fabric and tweezers with disposable tips

On plain surfaces in the drug preparation and administration units (floors, laminar flow hoods, and other surfaces) (Table 1) an area of 20x20 cm was wiped with tweezers in three standard directions (down, left, and right), whereas the surfaces smaller than $20 \times 20 \mathrm{~cm}$ were wiped in the same way but the exact area was recorded.

The wipe with $1.8 \mathrm{~mL}$ of equimolar water/methanol solution containing $20 \mathrm{ng} \mathrm{mL}^{-1}$ of internal standards, was

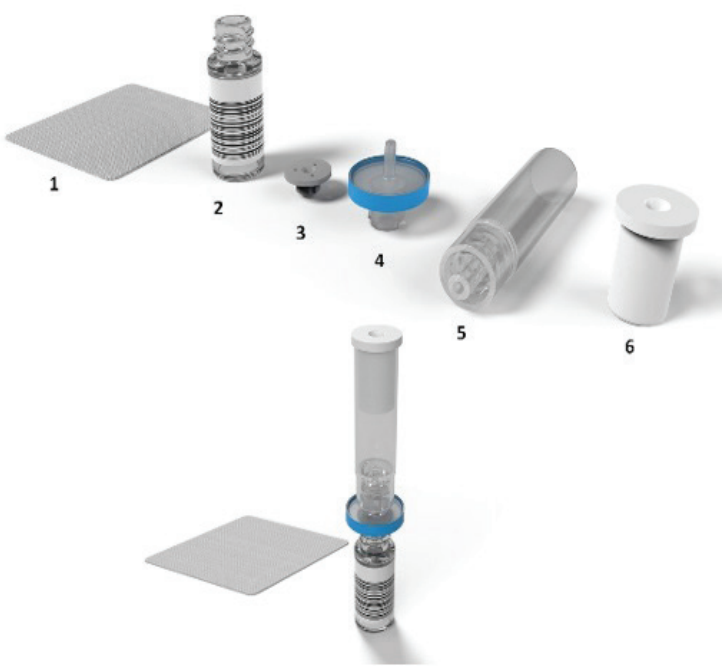

Figure 2 Wipe cartridge kit (WCK): 1) $5 \times 5 \mathrm{~cm}$, 3-layer nonwoven fabric; 2) $2 \mathrm{~mL}$ vial; 3) joint; 4) $0.2 \mu \mathrm{m} \mathrm{GHP}$ Acrodisc 13-mm filters; 5) cartridge; and 6) cartridge plunger with a hole for a $2.5 \mathrm{~mL}$ syringe placed inside the WCK in off-line mode using Automated Wipe Desorption (Chromline, Prato, Italy) installed on a Flex GC autosampler (EST Analytical, Fairfield, USA) equipped with two 50-position WCK trays and a $2.5 \mathrm{~mL}$ headspace syringe.

\section{Analytical procedures}

The twenty ADs were quantitated with a LC-MS/MS (Alliance e2695/Quattro Micro API, Waters, Milford, USA) using fragment ions produced via collision-induced fragmentation. 5-FU, DC, GEM, and CTB were analysed with a SeQuant ZIC-HILIC, $5 \mu \mathrm{m}, 200 \AA 2.1 \times 100 \mathrm{~mm}$ column (Cat. No. 1.50452.0001, Merck KGaA, Darmstadt, Germany) at $50{ }^{\circ} \mathrm{C}$ using $0.1 \mathrm{~mol} \mathrm{~L}^{-1}$ ammonium formate (A) and acetonitrile (B). The elution gradient used was the following: $0 \mathrm{~min}, 100 \% \mathrm{~B} ; 1.0 \mathrm{~min}, 80 \% \mathrm{~B} ; 10.0 \mathrm{~min}$, $70 \% \mathrm{~B} ; 12.0 \mathrm{~min}, 90 \% \mathrm{~B} ; 15.0 \mathrm{~min}, 100 \% \mathrm{~B}$. The other ADs were separated with an Atlantis T3, $3 \mu \mathrm{m} 2.1 \times 100 \mathrm{~mm}$ column (Cat. No. 186003718, Waters, Milford, USA) at $25{ }^{\circ} \mathrm{C}$ with a $0.1 \%$ formic acid solution (A) and a $0.1 \%$ formic acid in 60:40 acetonitrile:methanol solution (B) for the gradient (0.0-2.0 $\mathrm{min}, 5 \% \mathrm{~B} ; 2.1-17.0 \mathrm{~min}, 85 \% \mathrm{~B}$; 17.1-20.5 min, $85 \%$ B). For both chromatographic profiles the flow rate was $0.3 \mathrm{~mL} \mathrm{~min}^{-1}$ with $10.0 \mu \mathrm{L}$ of desorbed wipe injected into both columns. The MS utilised multiple reaction monitoring (MRM) for positive- and negative-ion 

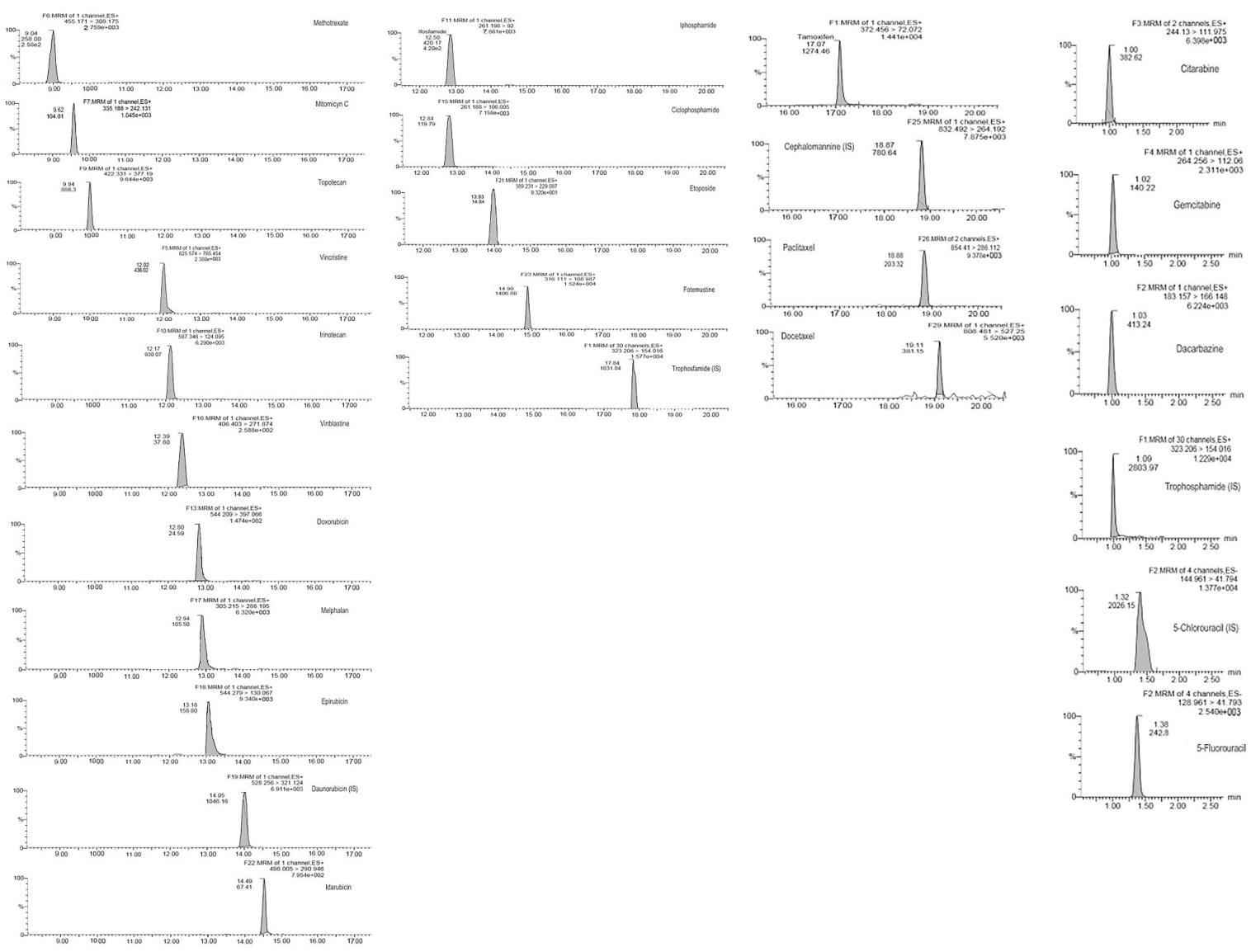

Figure 3 LC-MS/MS chromatograms of ADs standard at $1.25 \mathrm{ng} \mathrm{mL} \mathrm{L}^{-1}$ performed by Atlantis T3 (3a, 3b, 3c) and ZIC-HILIC (3d) columns. Four acquisition windows in MRM mode, with positive-and negative-ion electrospray ionization show retention time and area peak

electrospray ionization $\left(\mathrm{ESI}^{+}, \mathrm{ESI}^{-}\right)$acquisition windows (Figure 3).

Pt was analysed with an iCAPQ inductively coupled plasma (ICP)-MS (Thermo Fisher Scientific, Waltham, MA, USA) with a Cetac ASX520 autosampler (Cetac Technologies, Omaha, NE, USA), a PFA cyclonic spray chamber, and a 2.5-mm internal-diameter quartz injector. Pt levels were measured in the standard mode (STD), as follows: 1:20 dilution of wipe extraction solution with $1 \%$ hydrochloric acid; peristaltic pump speed: $40 \mathrm{rpm}$; nebuliser gas flow rate: $0.91 \mathrm{~L} \mathrm{~min}^{-1}$; radio frequency power: $1.550 \mathrm{~W}$; cool gas flow: $14 \mathrm{~L} \mathrm{~min}^{-1}$; and auxiliary gas flow: $0.89 \mathrm{~L} \mathrm{~min}^{-1}$. Dwell times were $50 \mathrm{~ms}$ for ${ }^{194} \mathrm{Pt}$ and $10 \mathrm{~ms}$ for internal standards, with 40 sweeps per replicate and three replicates per sample. Moreover, dwell times for ${ }^{114} \mathrm{In}$ were $1.0 \mathrm{~s}$, and $0.05 \mathrm{~s}$ for ${ }^{72} \mathrm{Ge}$, with 20 sweeps per replicate and three replicates per sample. The instrument was tuned daily to ensure optimisation.

Blank wipe samples and wipe samples spiked with the internal standard solution alone or with six calibration standards obtained from a mixed solution of all 21 ADs, were used to build a calibration curve at the following concentrations: $1.25,2.5,5.0,10.0,20.0,40 \mathrm{ng}$ per wipe. Five replicates for every standard were analysed, and the peak area ratio from each analyte and internal standard used to obtain the response factor plot. The slopes (m) and intercepts (b) of the calibration lines were estimated with the least-square linear regression analysis, using the following formula:

$$
y=m x+b
$$

where $y$ is the ratio between the chromatographic area of the analyte and its internal standard, and $\mathrm{x}$ is the concentration of the analyte.

The limit of detection (LOD) was calculated according to the formula:

$$
\mathrm{LOD}=\left(3 \mathrm{SE}_{\mathrm{b}}+\mathrm{b}\right) / \mathrm{m}
$$

where $\mathrm{SE}_{\mathrm{b}}$ is the standard error of the intercept.

The lower limit of quantification (LOQ) was then estimated in the same way using $10 \mathrm{SE}_{\mathrm{b}}$, which corresponds to $3.3 \mathrm{LOD}$.

The precision of the assay (as a coefficient of variation, $\mathrm{CV} \%$ ) was estimated both as within-session and as intersession repeatability.

Within-session accuracy was evaluated by recoveries (reported as the percentage ratio between the measured and the nominal concentrations) at all concentrations used for the calibration plot (Table 2). These accuracy values were 


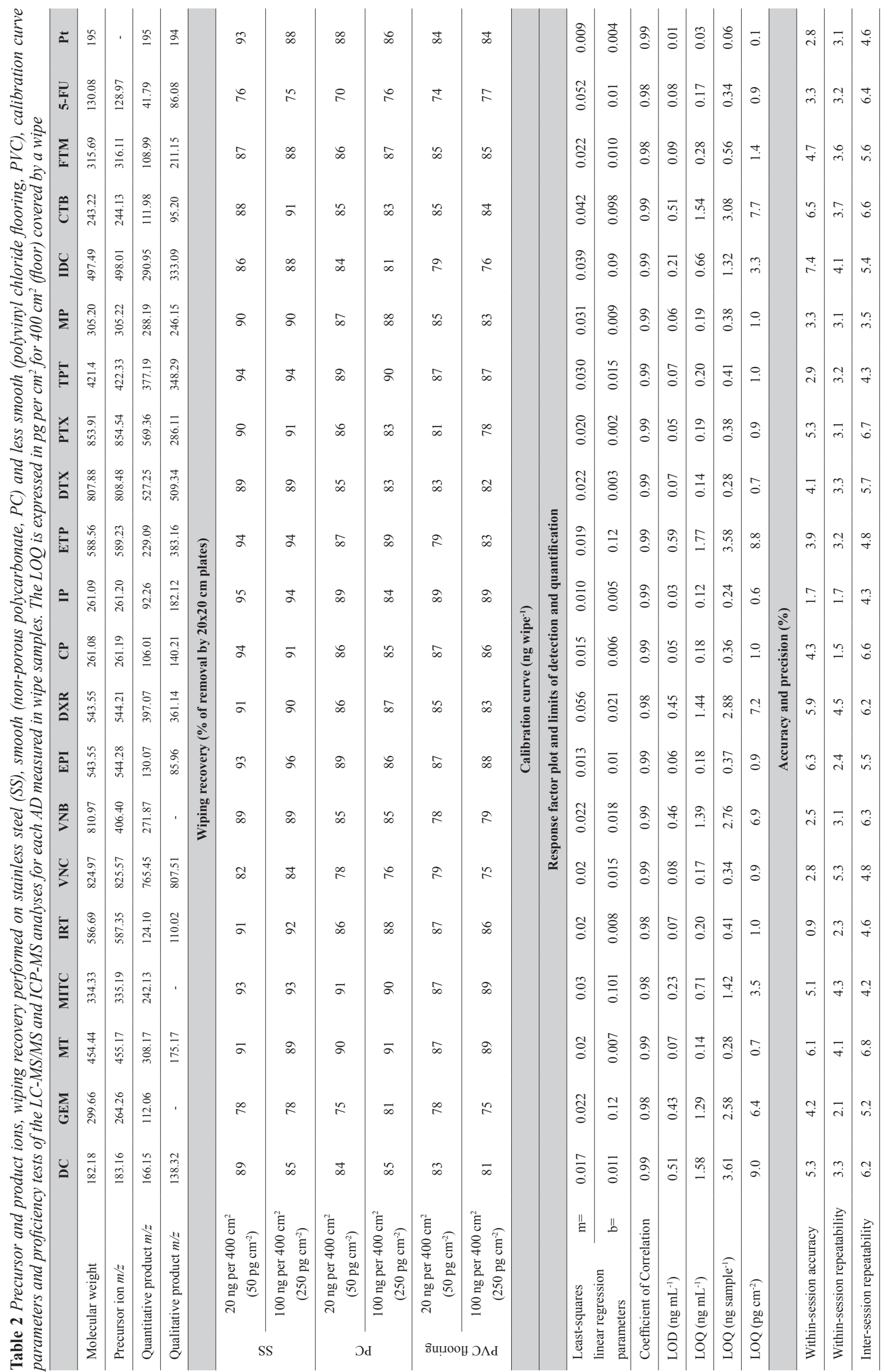


then compared with the US Food and Drug Administration requirements in order to validate our analytical methods.

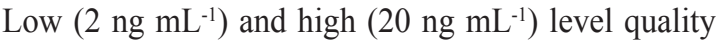
control samples (QCs) were prepared and processed in every analytical session from a fresh solution with 21 ADs with internal standards to ensure the intra- and inter-day repeatability of reported results.

\section{Validation study}

The wiping recoveries of each $\mathrm{AD}$ were evaluated in terms of the percentage of removal efficiency from spiked surfaces. To do that, we quantified additional wipe samples taken from stainless steel, smooth (non-porous polycarbonate) and less smooth (polyvinyl chloride flooring), $20 \times 20 \mathrm{~cm}$ brand new plates spiked to $20 \mathrm{ng}$ $\left(50 \mathrm{pg} \mathrm{cm}^{-2}\right)$ and $100 \mathrm{ng}\left(250 \mathrm{pg} \mathrm{cm}^{-2}\right)$ of AD. Spiked wipe sample stability was tested at $4{ }^{\circ} \mathrm{C}$ from 4 to $24 \mathrm{~h}$.

The desorption efficiencies were calculated as the percentage of response decline between the spiked wipes and the nominal AD solution analysed.

We also established the MS matrix effects in six replicates for each $\mathrm{AD}$ in terms of mean relative ionisation recovery for the analytes, calculated as the percentage of response decline between the analytes spiked into the eluate, obtained after extracting the blank wipe, and the analytes injected directly into the mobile phase.

The obtained data management were processed with the Stata data analysis and statistical software (StataCorp LLC, College Station, TX, USA).

\section{RESULTS}

\section{Wiping and desorption}

Our wiping procedure, with tweezers instead of a new pair of gloves as other authors do, reduced the sampling time (15 s per wiping), cost (as the price of the replaceable tweezer tips is much lower than that of gloves), and the risk of contamination, and the recoveries were over $75 \%$ (Table 2 ). The full insertion of the wipes into the holder and automation ensured desorption efficiencies close to $100 \%$ for all ADs. The filling speed for the $2.5 \mathrm{~mL}$ syringe was set to $30 \mu \mathrm{L} \mathrm{s}^{-1}$.

\section{Analyses}

Analytical curves were linear over the entire concentration range, with correlation coefficients $\left(\mathrm{r}^{2}\right)$ above 0.992 for all tested compounds. As the intra- and inter-day variability for all compounds ranged from 0.9-6.8 \%, the average accuracy and inter-day precision were within the acceptable range. The LOQs for wipe ADs were between 0.06 and 3.49 ng wipe $^{-1}$ (Table 2).

\section{Data distribution}

Of the 4,814 wipes taken 1,583 (604 in preparation units and 979 in administration units) were $\geq$ LOQ (33\%). Of these, 775 were taken before and 808 after the work shift.

Table 3 shows that of the 74,565 measurements, positive were 3,081 (1399 in preparation units and 1682 in administration units) or $4.1 \%$. Positive measurements for at least one AD before and after the work shift were 1,399 and 1,682, respectively. Most of them were determined on samples taken from "other surfaces" (waste containers, personal computers, support surfaces, intercoms, phones, and chairs), followed by the floors $(23.2 \%)$, laminar flow hoods (19.1\%), door handles (16.7\%), and what is referred to as "the bed area" (the bed, armchairs, drip shaft, and syringe pump) $(9.8 \%)$.

The six most frequently detected substances were $\mathrm{CP}$ (17.2\% of all CP measurements were positive), IP (15.4\% of all IP measurements were positive), GEM (8.6\%), Pt (5.4\%), and 5-FU (4.4\%), and PTX (4.1\%).

Table 4 shows the number of measurements $\geq$ LOQ as well as ranges by ADs.

\section{Surface exposure levels}

Because the values obtained showed a strongly skewed distribution, we decided to classify the data by the $90^{\text {th }}$ and the $75^{\text {th }}$ percentile instead of using normal distribution parameters. Table 5 shows the proposed limit surface exposure levels (SELs) for CP, IP, GEM, PTX, 5-FU, and $\mathrm{Pt}$, expressed in $\mathrm{pg} \mathrm{cm}^{-2}$ and derived from the percentiles of contamination levels for different categories of surfaces.

Table 3 Positive findings of at least one AD on workplace surfaces

\begin{tabular}{|c|c|c|c|c|c|c|c|}
\hline & \multicolumn{3}{|c|}{ Preparation units } & \multicolumn{3}{|c|}{ Administration units } & \multirow[b]{2}{*}{ Total } \\
\hline & B-WS & E-WS & $\sum$ & B-WS & E-WS & $\sum$ & \\
\hline Floor & 70 & 73 & 143 & 266 & 307 & 573 & 716 \\
\hline Door handle & 114 & 147 & 261 & 130 & 124 & 254 & 515 \\
\hline Bed area & N/A & N/A & $\mathrm{N} / \mathrm{A}$ & 160 & 144 & 304 & 304 \\
\hline Laminar flow hood & 293 & 296 & 589 & N/A & N/A & & 589 \\
\hline WC & N/A & N/A & & 63 & 69 & 132 & 132 \\
\hline Other surfaces & 179 & 227 & 406 & 206 & 213 & 419 & 825 \\
\hline Total & 656 & 743 & 1399 & 825 & 857 & 1682 & 3081 \\
\hline
\end{tabular}


Table 4 Measurements for each $A D$ and related minimum and maximum concentration values

\begin{tabular}{|c|c|c|c|c|c|}
\hline & $\begin{array}{c}\text { Number of meas- } \\
\text { urements }\end{array}$ & $\begin{array}{l}\text { Number of positive } \\
\text { measurements }\end{array}$ & $\begin{array}{l}\text { Percentage of positive } \\
\text { measurements }(\%)\end{array}$ & $\begin{array}{c}\text { Minimum } \\
\text { values sampled } \\
\left(\mathrm{pg} \mathrm{cm}^{-2}\right)\end{array}$ & $\begin{array}{c}\text { Maximum } \\
\text { values sampled } \\
\left(\mathrm{pg} \mathrm{cm}^{-2}\right)\end{array}$ \\
\hline $\mathrm{DC}$ & 4,701 & 70 & 1.5 & 0.8 & 8,175 \\
\hline GEM & 4,934 & 425 & 8.6 & 0.8 & 138,453 \\
\hline MT & 3,329 & 28 & 0.8 & 2 & 27,387 \\
\hline MITC & 4,569 & 12 & 0.3 & 2.8 & 463 \\
\hline IRT & 4,934 & 98 & 2.0 & 0.8 & 49,553 \\
\hline $\mathrm{VNC}$ & 3,341 & 17 & 0.5 & 2.5 & 416 \\
\hline VNB & 669 & 20 & 3.0 & 1.2 & 279 \\
\hline EPI & 4,934 & 27 & 0.5 & 1.2 & 1,364 \\
\hline DXR & 4,701 & 35 & 0.7 & 3 & 1,181 \\
\hline $\mathrm{CP}$ & 5,025 & 864 & 17.2 & 2 & 78,075 \\
\hline IP & 4,934 & 762 & 15.4 & 1.8 & 214,628 \\
\hline ETP & 4,904 & 27 & 0.6 & 3 & 1920 \\
\hline DTX & 4,702 & 74 & 1.6 & 1.2 & 27,478 \\
\hline PTX & 4,934 & 201 & 4.1 & 0.8 & 11,635 \\
\hline TPТ & 179 & 0 & 0.0 & 0 & --- \\
\hline MP & 1,481 & 0 & 0.0 & 0 & --- \\
\hline IDC & 2,513 & 27 & 1.1 & 4 & 1,485 \\
\hline CTB & 1,877 & 30 & 1.6 & 4 & 254,3 \\
\hline FTM & 320 & 2 & 0.6 & 2.4 & --- \\
\hline 5-FU & 4,586 & 201 & 4.4 & 3 & 236,097 \\
\hline $\mathrm{Pt}$ & 2,998 & 161 & 5.4 & 0.1 & 2,851 \\
\hline Total & 74,565 & 3,081 & & & \\
\hline
\end{tabular}

These limits were actually adopted by all the nine participating hospital pharmacies and administration units for good hygiene practice. For all other ADs, the analysed $50^{\text {th }}, 75^{\text {th }}$, and $90^{\text {th }}$ percentiles were lower than our LOQs.

\section{DISCUSSION}

Current analytical methods for biological monitoring are not sensitive or specific enough for ADs $(12,29,30)$. With modern ventilation resources at hand $\mathrm{AD}$ inhalation has become controlled and air sampling will soon be useless, which begs the question: which new validated environmental monitoring method will replace it. We recommend the wipe test, a method widely used by industrial hygienists and currently the only one able to detect ADs at levels as low as $\mathrm{pg} \mathrm{cm}^{-2}$.

The actual risk to healthcare workers depends on $\mathrm{AD}$ toxicity and how these drugs enter the body; this should guide its handling protocols. In general, dermal absorption is more likely to occur with drugs with a molecular weight of $<500 \mathrm{Da}$ and less likely for those $>1000 \mathrm{Da}$ (31-34). The Occupational Safety and Health Administration (35), United States Pharmacopeia (36) and the European Parliament Policy Recommendation (37) all suggest adopting an environmental monitoring program for ADs and using tools that facilitate easy interpretation of these results. Our procedure, as outlined in this paper, both monitors AD contamination of healthcare environment and reliably measures cleaning effectiveness and worker adherence to protocols.

The development of chromatographic methods for simultaneous analysis of polar and non-polar compounds has piqued the interest of the international scientific community (38), including our research group. More specifically, some authors $(13-15,21)$ have proposed LC methods for 5-FU resolution via a $\mathrm{C} 18$ stationary phase combining hydrophobic and polar selectivity. Since our goal was to analyse as many ADs as possible at the same time, given that cancer treatments often include more than one cytotoxic drug and that this increases the probability of having at least one positive finding, we preferred to use two LC columns: one for hydrophobic cytostatic drugs and one for the hydrophilic ones. The former employs Atlantis T3 columns: silica-based, reversed-phase $\mathrm{C} 18$ columns that provide balanced retention of low-polar and hydrophobic molecules. Their T3 bonding utilises a trifunctional C18 alkyl phase with a ligand density that promotes polar compound retention and aqueous mobile phase compatibility. The second, utilises the SeQuant ZIC-hydrophilic interaction liquid chromatography (HILIC) to separate polar and hydrophilic compounds, and its high-performance, 


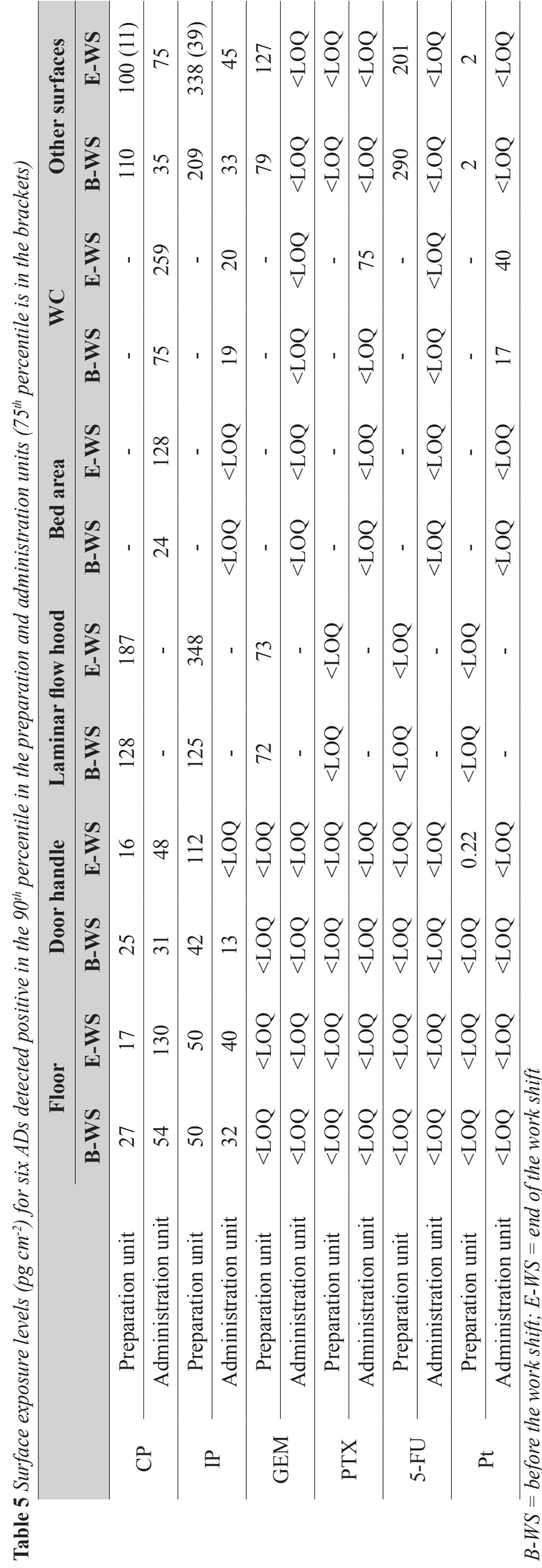

Zwitterionic stationary phase ensures reproducible retention of 5-FU, DC, and CTB which would otherwise have poor retention and are difficult to separate on reversed-phase LC columns. Simply put, HILIC is a normal-phase type of separation, but it can use reversed-phase type eluents. In recent years, it has received a lot of attention (39). The Three-Column Selector Valve developed by Waters has made possible automated switching of the two analytical columns between one analysis and the other. As a result of these innovations, we were able to come up with a novel LC-MS/MS approach capable of detecting twenty ADs. The off-line $x y z$ robotic system allows for automated consecutive wipe desorption without the need for manual operation. The WCK barcodes provided each wipe with a unique assembly tracking number for traceability. Furthermore, flexible profile monitoring enabled us to integrate all sampling management, data analysing processes, and software into the Bika Laboratory Information Management Systems (LIMS).

No governmental industrial hygiene association has yet set exposure limits for ADs since no safe exposure levels are known. Instead, the most commonly applied principle is "As Low As Reasonably Achievable" (ALARA), but interventions to reduce exposure as much as possible cannot be verified without quantitative evidence of environmental contamination. Perhaps the only environment where AD exposure can be monitored and limited is the workplace, and it is therefore imperative to do that. Furthermore, in agreement with Kromhout (40), we strongly support quantitative assessment of AD exposure, as it ensures better accuracy of exposure estimates in occupational and domestic settings.

Ubiquitous environmental contamination with ADs is the consequence of their massive use. There is hardly a hospital not handling them, which inevitably leads to the contamination of drug containers and cross-contamination of cytotoxic drug vials (41-44). Furthermore, patients carry contamination home (45), and eventually it reaches water (46). The SELs we propose take into account different aspects of $\mathrm{AD}$ contamination that may occur in the healthcare environment: from contamination with pure drug in the preparation units to contamination with its diluted and biological (e.g. urine, saliva, sweat) forms in the administration units at the beginning and end of the work shift (i. e. when the workplace is expected to be clean and when it is not). Their purpose is to verify worker compliance with procedures, cleaning efficacy, and persistence of pollution over time. Our SELs are in line with the TGVs proposed by Böhlandt and Schierl (26) for 5-FU and Pt, the $\mathrm{HGVs}$ indicated by Hedmer and Wohlfart (27) for CP and IP, and with the cytotoxic-independent target value of $100 \mathrm{pg} \mathrm{cm}^{-2}$ proposed by Kiffmeyer et al. (22), based on the $90^{\text {th }}$ percentile of the results.

We have therefore created a traffic-light colour-coding system for $21 \mathrm{ADs}$, where values between the LOQ and the $75^{\text {th }}$ percentile are coloured green, between the $75^{\text {th }}$ and the 


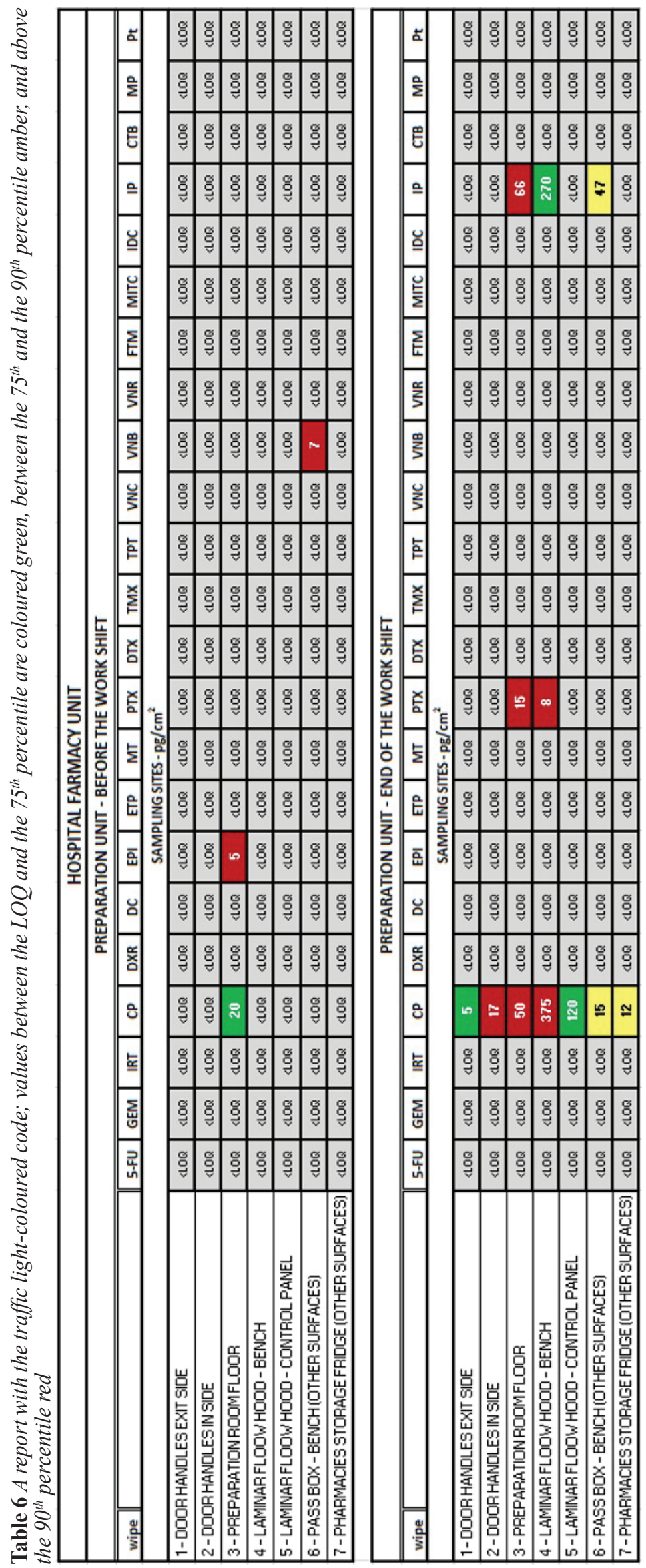


$90^{\text {th }}$ percentile amber, and above the $90^{\text {th }}$ percentile red for user-friendly monitoring in healthcare environment at the beginning and at the end of the work shift. Table 6 illustrates the colour-coding system used by an AD pharmacy preparation unit in monitoring reports.

They will help in interpreting monitoring results, that is, until official threshold limits have been defined. In addition, this could facilitate comparison with other countries in order to extend the database and identify the best practices for handling drugs under different workplace conditions.

As for the wipe-sampling approach described in this study, we believe it can also be applied to other relevant substances, such as monoclonal antibodies and antibiotics on NIOSH's recent list of hazardous drugs.

\section{Conflicts of interests}

The authors declare no conflicts of interest with respect to research, authorship, and/or publication of this article.

\section{REFERENCES}

1. World Cancer Research Fund International (WCRF). Worldwide data [displayed 1 August 2018]. Available at http://www.wcrf.org/int/cancer-facts-figures/worldwide-data

2. Transparency Market Research. Anti-cancer drugs market global industry analysis, size, share, growth, trends, and forecast 2016 - 2024. In: Global anti-cancer drugs market: competitive landscape and region-wise outlook [displayed 1 August 2018]. Available at https://www. transparencymarketresearch.com/anticancer-drugs-market. html

3. Report Buyer Ltd. Market research and forecast of antineoplastic drugs in China 2016-2021. In: Smmary [displayed 1 August 2018]. Available at https://www. reportbuyer.com/product/4696059/market-research-andforecast-of-antineoplastic-drugs-in-china-2016-2021.html

4. Zion Market Research. Cancer drugs market by therapy (immunotherapy, targeted therapy, chemotherapy, hormone therapy and others) for breast cancer, blood cancer, gastrointestinal cancer, prostate cancer, skin cancer, lung cancer and other cancer: global industry perspective, comprehensive analysis and forecast, 2015-2021. Florida, United States; 2016. [displayed 1 August 2018]. Available at https://www.zionmarketresearch.com/news/global-cancerdrugs-market

5. Allied Market Research. Oncology/cancer drugs market by therapeutic modalities (chemotherapy, targeted therapy, immunotherapy, hormonal), cancer types (blood, breast, gastrointestinal, prostate, skin, respiratory/lung cancer) Global opportunity analysis and industry forecast, 20132020. Pune, India; 2015. In: Global Oncology/Cancer Drugs Market [displayed 1 August 2018]. Available at https://www. alliedmarketresearch.com/oncology-cancer-drugs-market

6. National Institute for Occupational Safety and Health (NIOSH). NIOSH List of antineoplastic and other hazardous drugs in healthcare settings, 2016 [displayed 1 August 2018]. Available at http://bit.ly/2i4gE2a
7. International Agency for Research on Cancer (IARC). Agents Classified by the IARC Monographs. Volumes 1-116. Lyon: IARC; 2016.

8. Ratner PA, Spinelli JJ, Beking K, Lorenzi M, Chow Y, Teschke K, Le ND, Gallagher RP, Dimich-Ward H. Cancer incidence and adverse pregnancy outcome in registered nurses potentially exposed to antineoplastic drugs. BMC Nursing 2010;9:15. doi: 10.1186/1472-6955-9-15

9. Hall AL, Demers PA, Astrakianakis G, Ge C, Peters CE. Estimating national-level exposure to antineoplastic agents in the workplace: CAREX Canada findings and future research needs. Ann Work Expos Heal 2017;61:656-8. doi: 10.1093/annweh/wxx042

10. Beretta G, Fasola G. Organizzazione dell'oncologia in Italia [The set up of oncology services in Italy, in Italian] [displayed 1 August 2018]. Available at http://www.aiom.it/C_Common/ Download.asp? file $=/ \$$ Site $\$ /$ files $/$ doc $/$ AIOM-Servizi $/$ slide/20170427RM_03 Beretta.pdf

11. Kopjar N, Želježić D, Kašuba V, Rozgaj R. Antineoplastični lijekovi kao čimbenik rizika u radnom okolišu: mehanizmi djelovanja na razini stanice i pregled metoda za otkrivanje njihovih genotoksičnih učinaka [Antineoplastic drugs as a potential risk factor in occupational settings: mechanisms of action at the cell level, genotoxic effects, and their detection using different biomarkers, in Croatian]. Arh Hig Rada Toksikol 2010;61:121-46. doi: 10.2478/10004-1254-612010-2025

12. Kibby T. A review of surface wipe sampling compared to biologic monitoring for occupational exposure to antineoplastic drugs. J Occup Environ Hyg 2017;14:159-74. doi: 10.1080/15459624.2016.1237026

13. Bobin-Dubigeon C, Amiand M, Percheron C, Audeval C, Rochard S, Leynia P, Bard JM. A new, validated wipesampling procedure coupled to LC-MS analysis for the simultaneous determination of 5-fluorouracil, doxorubicin and cyclophosphamide in surface contamination. J Anal Toxicol 2013;37:433-9. doi: 10.1093/jat/bkt045

14. da Silva CB, Julio IP, Donadel GE, Martins I. UPLC-MS/ MS method for simultaneous determination of cyclophosphamide, docetaxel, doxorubicin and 5-fluorouracil in surface samples. J Pharmacol Tox Met 2016;82:68-73. doi: 10.1016/j.vasen.2016.08.004

15. Pretty JR, Connor TH, Spasojevic I, Kurtz KS, McLaurin JL, B'Hymer C, Debord G. Sampling and mass spectrometric analytical methods for five antineoplastic drugs in the healthcare environment. J Oncol Pharm Pract 2012;18:23-36. doi: $10.1177 / 1078155210389215$

16. Roland C, Caron N, Bussières JF. Multicenter study of environmental contamination with cyclophosphamide, ifosfamide, and methotrexate in 66 Canadian hospitals: A 2016 follow-up study. J Occup Environ Hyg 2017; 14:661-9. doi: 10.1080/15459624.2017.1316389

17. Thulin H, Sundberg E, Hansson K, Cole J, Hartley-Asp B. Occupational exposure to nor-nitrogen mustard: chemical and biological monitoring. Toxicol Ind Health 1995;11:89-97. doi: 10.1177/074823379501100108

18. Turci R, Minoia C, Sottani C, Coghi R, Severi P, Castriotta C, Del Bianco M, Imbriani M. Occupational exposure to antineoplastic drugs in seven Italian hospitals: the effect of quality assurance and adherence to guidelines. J Oncol Pharm Pract 2011;17:320-32. doi: 10.1177/1078155210381931 
19. Viegas S, Pádua M, Veiga AC, Carolino E, Gomes M. Antineoplastic drugs contamination of workplace surfaces in two Portuguese hospitals. Environ Monit Assess 2014;186:7807-18. doi: 10.1007/s10661-014-3969-1

20. Yoshida J, Koda S, Nishida S, Yoshida T, Miyajima K, Kumagai S. Association between occupational exposure levels of antineoplastic drugs and work environment in five hospitals in Japan. J Oncol Pharm Pract 2011;17:29-38. doi: $10.1177 / 1078155210380485$

21. Colombo M, Jeronimo M, Astrakianakis G, Apte C, Hon CY. Wipe sampling method and evaluation of environmental variables for assessing surface contamination of 10 antineoplastic drugs by liquid chromatography/tandem mass spectrometry. Ann Work Expos Heal 2017;61:1003-14. doi 10.1093/annweh/wxx070

22. Kiffmeyer TK, Tuerk J, Hahn M, Stuetzer H, Hadtstein C, Heinemann A, Eickmann U. Application and assessment of a regular environmental monitoring of the antineoplastic drug contamination level in pharmacies - the MEWIP project. Ann Occup Hyg 2013;57:444-55. doi: 10.1093/annhyg/mes081

23. Nussbaumer S, Geiser L, Sadeghipour F, Hochstrasser D, Bonnabry P, Veuthey JL, Fleury-Souverain S. Wipe sampling procedure coupled to LC-MS/MS analysis for the simultaneous determination of 10 cytotoxic drugs on different surfaces. Anal Bioanal Chem 2012;402:2499-209. doi 10.1007/s00216-011-5157-2

24. Sessink PJM. Environmental contamination with cytostatic drugs: past, present and future. Safety Consideration in Oncology Pharmacy (Special edition) 2011 [displayed 1 August 2018]. Available at https://pdfs.semanticscholar. org/8652/4d606dbd8e116ca2c26b1ec70d3f81cfe272.pdf

25. Schierl R, Böhlandt A, Nowak D. Guidance values for surface monitoring of antineoplastic drugs in German pharmacies Ann Occup Hyg 2009;53:703-11. doi: 10.1093/annhyg/ mep050

26. Böhlandt A, Schierl R. Benefits of wipe sampling: evaluation of long-term 5-fluorouracil and platinum monitoring data. Pharm Technol Hosp Pharm 2016;1:139-50. doi: 10.1515/ pthp-2016-0010

27. Hedmer M, Wohlfart G. Hygienic guidance values for wipe sampling of antineoplastic drugs in Swedish hospitals. J Environ Monitor 2012;14:1968-75. doi: 10.1039/ C2EM10704J

28. Sottani C, Grignani E, Oddone E, Dezza B, Negri S, Villani S, Cottica D. Monitoring surface contamination by antineoplastic drugs in Italian hospitals: performance-based hygienic guidance values (HGVs) project. Ann Work Expos Heal 2017;61:994-1002. doi: 10.1093/annweh/wxx065

29. Dugheri S, Bonari A, Pompilio I, Gentili M, Montalti M, Mucci N, Arcangeli G. A new automated gas chromatography/ solid phase microextraction procedure for determining $\alpha$-fluoro- $\beta$-alanine in urine. Malaysian J Anal Sci 2017;21:1091-100. doi: 10.17576/mjas-2017-2105-11

30. Ensslin AS, Pethran A, Schierl R, Fruhmann G. Urinary platinum in hospital personnel occupationally exposed to platinum-containing antineoplastic drugs. Int Arch Occ Env Hea 1994;65:339-42. doi: 10.1007/BF00405699

31. Connor TH, Smith JP. New approaches to wipe sampling methods for antineoplastic and other hazardous drugs in healthcare settings. Pharm Technol Hosp Pharm 2016;1:10714. doi: 10.1515/pthp-2016-0009
32. Khandavilli S, Panchagnula R. Studies of the skin permeation of lipophilic drugs: paclitaxel. Pharmazie 2007;62:471-3. doi: $10.1691 / \mathrm{ph} .2007 .6 .6044$

33. Odraska P, Mazurova E, Dolezalova L, Blaha L. In vitro evaluation of the permeation of cytotoxic drugs through reconstructed human epidermis and oral epithelium. Klin Onkol 2011;24:195-202. PMID: 21714452

34. Fransman W1, Kager H, Meijster T, Heederik D, Kromhout H, Portengen L, Blaauboer BJ. Leukemia from dermal exposure to cyclophosphamide among nurses in The Netherlands: quantitative assessment of the risk. Ann Occup Hyg 2014;58:271-82. doi: 10.1093/annhyg/met077

35. US Department of Labor. Occupational Safety and Health Administration. Controlling Occupational Exposure to Hazardous Drugs [displayed 1 August 2018]. Available at https://www.osha.gov/SLTC/hazardousdrugs/controlling_ occex_hazardousdrugs.html\#occ_environmental

36. United States Pharmacopeia (USP). USP General Chapter $<800>$ Hazardous Drugs - Handling in Healthcare Settings, 2017 [displayed 1 August 2018]. Available at http://www. usp.org/sites/default/files/usp/document/our-work/ healthcare-quality-safety/general-chapter-800.pdf

37. European Biosafety Network. Preventing Occupational Exposure to Cytotoxic and Other Hazardous Drugs European Policy Recommendations, 2016 [displayed 1 August 2018]. Available at http://www. europeanbiosafetynetwork.eu/wp-content/uploads/2016/05/ Exposure-to-Cytotoxic-Drugs_Recommendation DINA4_10-03-16.pdf

38. Marie P, Christophe C, Manon R, Marc M, Charleric B, Patrice V. Environmental monitoring by surface sampling for cytotoxics: a review. Environ Monit Assess 2017;189:52. doi: 10.1007/s10661-016-5762-9

39. Kawachi Y, Ikegami T, Takubo H, Ikegami Y, Miyamoto M, Tanaka N. Chromatographic characterization of hydrophilic interaction liquid chromatography stationary phases: hydrophilicity, charge effects, structural selectivity, and separation efficiency. J Chromatogr A 2011;1218:5903-19. doi: 10.1016/j.chroma.2011.06.048

40. Kromhout H. Hygiene without numbers. Ann Occup Hyg 2016;60:403-4. doi: 10.1093/annhyg/mev096

41. Connor TH, Sessink PJ, Harrison BR, Pretty JR, Peters BG, Alfaro RM, Bilos A, Beckmann G, Bing MR, Anderson LM, Dechristoforo R. Surface contamination of chemotherapy drug vials and evaluation of new vial-cleaning techniques: results of three studies. Am J Health-Syst Ph 2005;62:475-84. PMID: 15745910

42. Favier B, Gilles L, Ardiet C, Latour JF. External contamination of vials containing cytotoxic agents supplied by pharmaceutical manufacturers. J Oncol Pharm Pract 2003;9:15-20. doi: 10.1191/1078155203jp102oa

43. Fleury-Souverain S, Nussbaumer S, Mattiuzzo M, Bonnabry P. Determination of the external contamination and crosscontamination by cytotoxic drugs on the surfaces of vials available on the Swiss market. J Oncol Pharm Pract 2014;20:100-11. doi: 10.1177/1078155213482683

44. Naito T, Osawa T, Suzuki N, Goto T, Takada A, Nakamichi H, Onuki Y, Imai K, Nakanishi K, Kawakami J. Comparison of contamination levels on the exterior surfaces of vials containing platinum anticancer drugs in Japan. Biol Pharm Bull 2012;35:2043-9. doi: 10.1248/bpb.b12-00628 
45. Yuki M, Sekine S, Takase K, Ishida T, Sessink PJ. Exposure of family members to antineoplastic drugs via excreta of treated cancer patients. J Oncol Pharm Pract 2013;19:208-17. doi: $10.1177 / 1078155212459667$
46. Kümmerer K, Haiß A, Schuster A, Hein A, Ebert I. Antineoplastic compounds in the environment-substances of special concern. Environ Sci Pollut Res Int 2016;23:14791804. doi: $10.1007 / \mathrm{s} 11356-014-3902-8$

\section{Novi pristup procjeni profesionalne izloženosti antineoplasticima u bolničkom okruženju}

Zbog profesionalnih rizika koje donose, s citotoksičnim antineoplasticima potrebno je sigurno rukovati. U ovom članku predstavljamo validirani inovativan protokol kojim se istodobno mogu pratiti razine dvadeset jednog antineoplastika u zdravstvenim ustanovama te predlažemo razine površinske izloženosti (engl. surface exposure levels, krat. SELs) koje bi trebale olakšati tumačenje dobivenih rezultata praćenja, budući da trenutačno nisu propisane granične vrijednosti profesionalne izloženosti antineoplasticima. Rezultate praćenja onečišćenja antineoplasticima prikupili smo od devet talijanskih bolnica od 2008. do 2017., a obuhvaćaju 74.565 mjerenja 4.814 uzoraka prikupljenih brisanjem površina namjenskim maramicama (brisom). Ovakav je protokol upravo zbog izvrsne iskorištenosti i osjetljivosti analitičkih metoda te inovativne automatizacije desorpcije pogodan za rutinsko praćenje izloženosti u bolničkom okruženju. Onečišćenje antineoplasticima utvrđeno je u 3.081 mjerenju, što potvrđuje rizik od izloženosti u zdravstvenih radnika. Uzimanjem uzoraka na početku i kraju radne smjene omogućen je izračun vrijednosti unutar 75. i 90. percentila za svaki antineoplastik za jedinice u kojima se oni pripremaju i primjenjuju. Na temelju tih izračuna osmislili smo semaforski sustav boja koji olakšava tumačenje rezultata, a predložene razine površinske izloženosti poslužit će kao dobar temelj za poboljšanje sigurnosti na radnome mjestu i smanjenje onečišćenja.

KLJUČNE RIJEČI: bris test; masena spektrometrija s induktivno spregnutom plazmom; masena spektrometrija s tekućinskom kromatografijom; onečišćenje površina; zaštita na radu 